\title{
Hur tänkte Tumme? Om runstenen i Tuna gärde.
}

\section{Martin Hansson}

\section{Inledning}

Forskningen om runstenar började redan på 1600-talet med Johannes Bureus uppteckningar och sammanställningar av var dessa fantasieggande monument förekom och vad de representerade. Sedan dess har forskningen om runstenar fortgått. Inskrifternas och figurernas betydelse och symbolik har tolkats och diskuterats precis som runstenarnas placering i landskapet. Runstenar räknas ju som fornlämningar, men till skillnad från andra fornlämningar har runstenar egentligen aldrig varit föremål för arkeologiska undersökningar i form av utgrävningar. Kanske är detta en konsekvens av att forskningen till stora delar har varit inriktad på inskrifternas betydelse, men också ett utslag av att man inte sett det som motiverat att gräva intill en runsten. Vad skulle man hitta? Är det inte inskriften som är det intressanta? Få undersökningar har överhuvudtaget gjorts av ett in situ stående runstensmonument, däremot har flera undersökningar gjorts vid gotländska bildstenar (se Ljung \& Thedéen 2009; Andreeff 2012).

Runstenarnas placering i landskapet är dock en nyckel till förståelsen av vad dessa monument haft för betydelse och vad man velat åstadkomma med att resa dem (jfr Zachrisson 1998, s. 165ff). Genom studiet av runstenarnas placering i landskapet får vi en bättre förståelse för det sammanhang där den språkliga texten har formulerats. Med en sådan utgångspunkt kan arkeologiska undersökningar vid ett runstensmonument faktiskt bidra med avgörande kunskap. Syftet med den här artikeln är att diskutera en runsten i Småland, Sm 42 i Tuna by vid Ryssby strax öster om Ljungby, som var föremål för en arkeologisk forskningsundersökning sommaren 2013 (Hansson \& Stille 2014). Tanken är att presentera resultaten samt att diskutera en del hypoteser kring varför runstenen restes på just den här platsen.

Undersökningen var en del av projektet "Runstenar i Tiohärad "där Per Stille är en av de drivande krafterna (Stille 2007). Hans stora kunskap om runstenar, runristare och runinskrifter är en grundpelare inom projektet, där vi på mikronivå vill studera inte bara varför runstenar restes på platser där de gjordes, utan också hur de upplevdes i landskapet. Till skillnad från många andra projekt kring runstenar så är det här projektet uttalat tvärvetenskapligt till sin karaktär och innehåller både arkeologiska, kulturgeografiska och lingvistiska analyser.

Undersökningen gjordes som ett samarbete mellan Lunds universitet, Linnéuniversitetet, Kulturparken Småland och Kronobergs Arkeologiska Förening. Medlemmar från föreningen deltog i fältarbetet och bidrog stort till resultatet, såväl genom sina grävinsat- 
ser som genom att bidra till diskussioner om vikingatidens samhälle. Undersökningen finansierades via anslag från Lennart J Hägglunds Stiftelse, Berit Wallenberg stiftelse och Hallenbladska fonden.

\section{En runstens plats i kulturlandskapet}

Runstenen i Tuna by (Sm 42) står i en öppen hagmark i anslutning till åkermark cirka femtiofem meter från Ryssbysjöns strand på dess västra sida (fig 1). Texten omtalar att den är rest över Assur som var kung Haralds skeppsman. Inskriften lyder "tumi x risit : stin : thansi : iftir $\mathrm{x}$ asur : bruthur $\mathrm{x} \sin \mathrm{x}$ than : ar : uar : skibari :hrhls : ku I nuks : ", i nusvensk översättning: "Tumme reste denna sten efter Assur, sin broder, som var skeppsman åt kung Harald ”. (Gustavsson 2008, s. 203). Vilken kung Harald som avses är oklart även om flera alternativ diskuterats (se nedan).

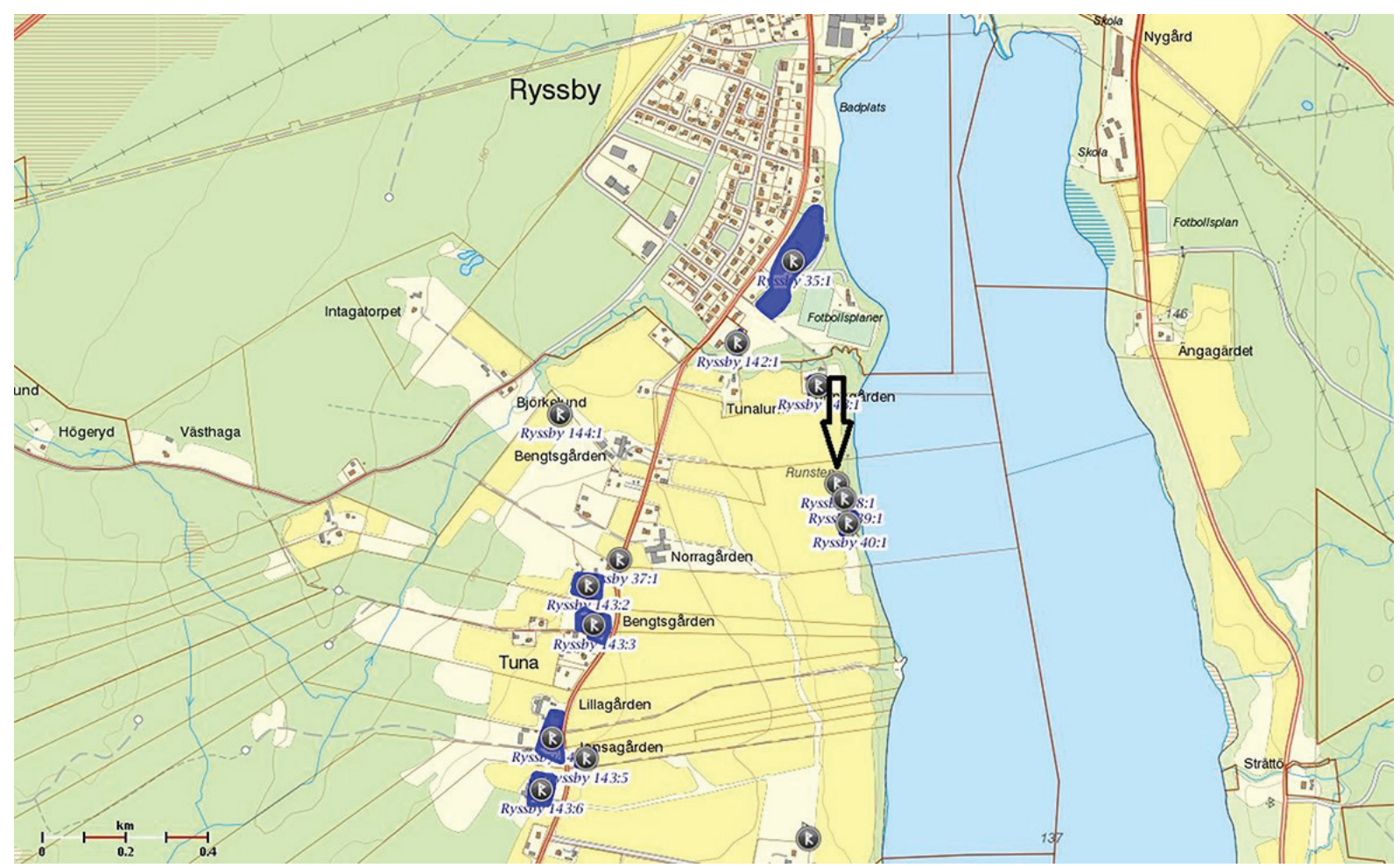

Fig. 1. Fornlämningsmiljön kring Tuna by, Ryssby socken. Pilen markerar läget för runstenen Sm 42, som är registrerad som RAÄ 38:1 i fornminnesregistret.

Alldeles norr och väster om runstenen finns odlad mark, medan det åt öster och söder är gräsbevuxen hagmark som idag betas. Hagmarken utgör strandzon mot sjön. Cirka trettio meter söder om runstenen ligger ett gravfält bestående av åtta högar och nittio meter söder om runstenen finns ytterligare ett gravfält bestående av tretton högar. Ytan mellan de båda gravfälten är odlad och det är möjligt att de en gång utgjort ett sammanhängande gravfält. Inga av gravarna är undersökta, men gravtypen dateras vanligen till vikingatid i regionen (Hansson 1998).

Vikingatiden är starkt representerad i Ryssby socken genom ett antal gravfält. Invid kyrkan, där det för övrigt hittats ytterligare en runsten samt två runstensfragment, (Sm 
39, 40, 41) (Jansson 1978) finns ett vikingatida höggravfält, och ungefär 400 meter nord och nordväst om runstenen finns ytterligare två höggravfält med sammanlagt närmare 90 gravar. På det ena av detta undersökte Carl Wibling två högar år 1890. I den ena påträffades ett brandlager med den undre delen till en oval spännbuckla av brons, i den andra ett brandlager med brända ben, kol och aska men inga gravgåvor (SHM 8923:3). Spännbucklan daterar graven till 900-talet.

Det finns även uppgifter om att ett vikingatida skattfynd påträffats i Tuna by. I samband med att arkeologen Nils Gustaf Bruzelius 1855 undersökte två högar på gravfältet vid Ryssby kyrka gjorde han även noteringar om att man påträffat mynt i Tuna by. Enligt Bruzelius sade befolkningen att det tidigare legat en köping eller stad på Tunas ägor och att man vid plöjning ska ha påträffat stenlagda gator och gamla silvermynt. En gammal kvinna skulle några år tidigare ha påträffat 12 silvermynt av vilka bara ett tillvaratagits, ett mynt som enligt Bruzelius var ett engelskt mynt präglat under tidigt 1000-tal under Knut den store (Knutsson 1995). Från Ryssby socken är för övrigt ytterligare ett skattfynd känt, från Östraby strax nordost om kyrkbyn Ryssby. Här hittades vid dikesgrävning 1858 ett skattfynd på ca 330 g silver, bestående av 131 mynt (54 danska, 71 tyska, 6 engelska) samt bitsilver. De yngsta mynten är präglade kring 1050-1060 varför skatten bör ha lagts ned kort därefter (G Larsson 1978, s. 13).

Ortnamnet Tuna är intressant i sammanhanget. Tuna har av ortnamnsforskare antagits haft betydelsen "gård”, "inhägnad” eller kanske "tomt”, men frågan är vad det varit för typ av gård. I Mälardalen har flera forskare kopplat samman -tuna orter med centralplatser under järnålder och tidig medeltid med varierande framgång (jfr Holmberg 1969, Olsson 1976, Hyenstrand 1982). I det skriftliga källmaterialet omnämns Tuna i Ryssby socken dock förhållandevis sent. Första gången är år 1400, då Birger Trolle d.ä. fick två gårdar i byn av sin halvbror, riddaren Erik Nilsson (bjälke). Gårdarna var Eriks arv från fadern, riddaren Nils Dannes vilken bodde i Böksholm i Drev socken norr om Växjö, där han av allt att döma hade en befäst sätesgård (Holmberg 1969, s. 240; Hansson 2001, s. 159f, 335 anf litt). Under 1400-talet fanns minst sex gårdar i Tuna by som ägdes av olika frälsemän, ingen av dem förefaller dock ha haft sin sätesgård i byn. I 1500-talets jordeböcker hade Tuna by sju gårdar, sex som ägdes av frälsemän och en som brukades av en kyrkolandbo, Lunnegården. Utsädesuppgifterna kring 1560 visar att byns gårdar var olika stora (Holmberg 1969, s. 240f). Enligt fornlämningsbilden existerade Tuna som bebyggelse redan under vikingatiden och de många gravfälten tyder på att byn redan då bör ha bestått av flera gårdar.

\section{Kartornas vittnesbörd}

I de äldsta kartorna över Tuna framträder en by med sju gårdar. Skeda, söder om Tuna by var ett eget hemman men hade sina ägor samfällt med byn enligt storskifteskartan från 1801-02. Byns övriga gårdar låg med ett undantag samlade på rad i två grupper längs den nord-sydliga landsvägen genom byn. Undantaget var Lunnegården som låg ensamt 
en bit norr om de övriga gårdarna. I samband med undersökningen gjordes en analys av det äldsta historiska kartmaterialet över Tuna by. Denna gjordes av kulturgeograf, fil. dr. Ådel Vestbö-Franzén vid Jönköpings läns museum. Tanken med att analysera ett historiskt kartmaterial är att detta ska kunna avslöja spår av äldre strukturer i landskapet från tider före kartornas tillkomst (jfr Tollin 1991).

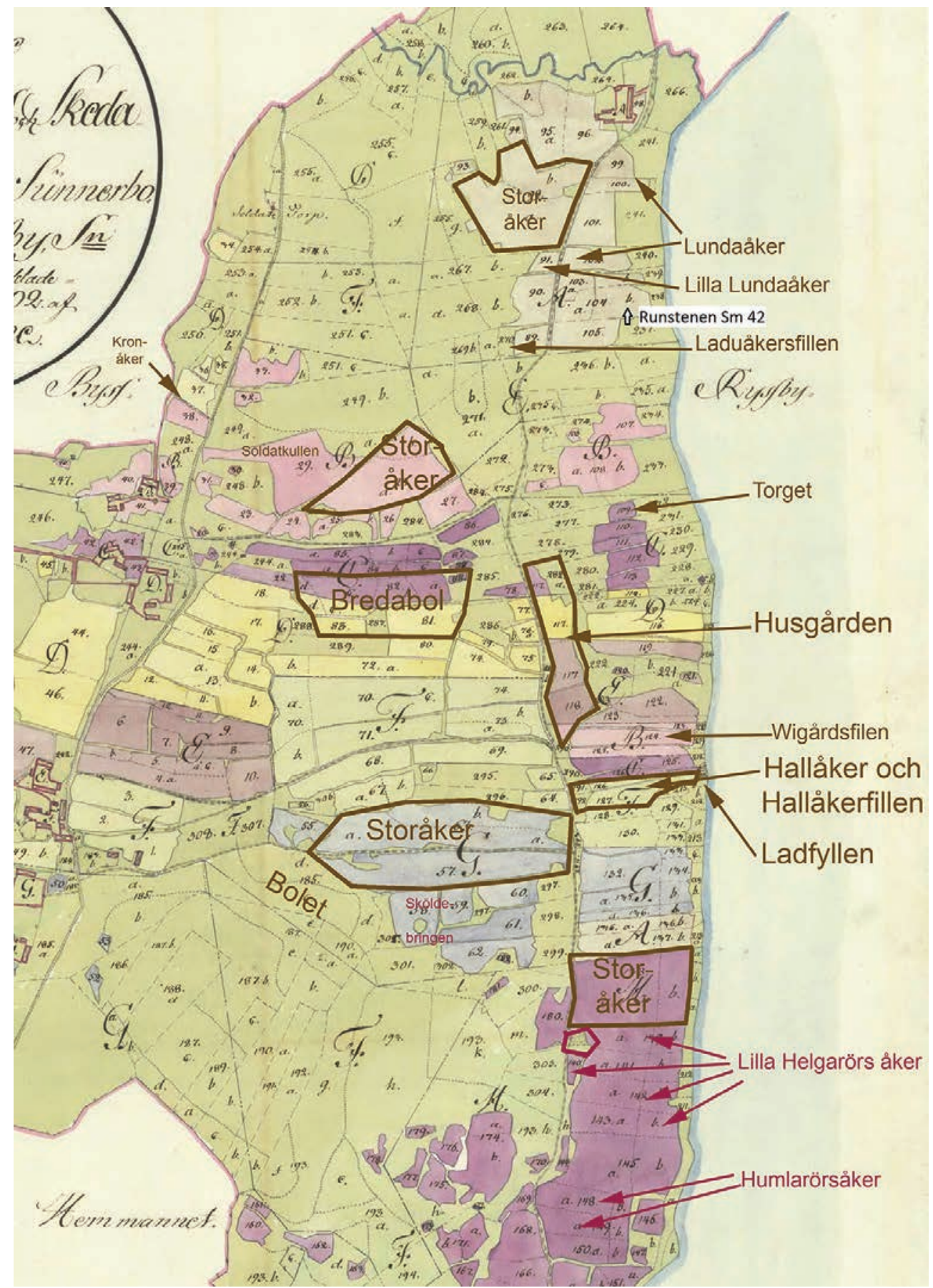

Fig. 2 Utdrag ur 1801 års storskifteskarta över Tuna by med bebyggelseindikerande ägonamn markerade. Runstenens läge markerat i norra delen av byområdet. De dåvarande gårdarna syns i kartans vänstra del, förutom Lunnegård som ligger ensamt längst i norr. Kartanalys av Aadel Vestbö-Franzén, Jönköpings läns museum. Fri skala. 
Den äldsta historiska kartan över Tuna by är en geometrisk avmätning från 1703 över Tuna Bengtsgård (F59-55:1). Här syns byns tomter, åker och äng översiktligt, men runstenen är inte markerad. Det är den inte heller på den mer detaljerade storskifteskartan från 1801-02 (F59-55:3). Här ligger gårdarna i Tuna by i sitt nuvarande läge längs med vägen i kanten av inägomarken, vars åker och äng sträcker sig ner mot sjön i öster. Inägan delas i en västlig och en östlig del av en väg som löper i nordsydlig riktning genom byns marker. Det finns dock ingen bebyggelse längs denna väg på kartan.

I kartan från 1801 kallas åkrarna närmast runstenen för Runnåker. Detta kan möjligen anspela på runstenen, men förleden runn- skulle också kunna syfta till en rönndominerad trädvegetation i anslutning till åkern. Men det förefaller som om runn-förleden här skall knytas till runstenen. Lantmätaren använder begreppet fil eller fill för små ängsstycken mellan åkerytor, det som på andra ställen kallas ren. Ett sådant litet ängsstycke ligger strax norr om runstenen och betecknas som Runnesfilen. Ägan där runstenen står betecknas som Stenfillen och används som äng. På kartan brukas marken norr och väster om runstenen som åker 1801-02, precis som idag. Däremot var området söder om runstenen ängsmark (Fig 2). Möjligen ska ordet "sten” i marknamnet referera till själva runstenen eftersom topografin i närområdet är förhållandevis stenfri och marken sandig.

Kartan från 1801 är lämpligast att använda vid en retrospektiv studie av Tuna. Den visar att runstenen är belägen ganska långt från Tuna bys bytomt och norr om byns centrala åkermark. Den nordligaste av gårdarna, Lunnegården var skild från resten av byn och hade sin åker och äng samlad strax söder om gårdsbebyggelsen och den å som löper ut i Ryssbysjön. Norr om ån fortsätter Tunas ägor i form av ängar upp mot utmarksområdet där Ryssby och Tuna byar möter. I detta område finns ett yngre järnåldersgravfält med 80 högar. En analys av ägouppdelningen av åker och äng antyder att Lunnegården inte är infogat i samma primära tegstruktur som resten av byn. Gårdens sydligaste åkertegar ligger inom ett område som troligen är sekundärt uppdelat. I detta område återfinns även runstenen.

Från Ryssby leder två vägar söderut. Vägskälet där vägarna skiljs åt är beläget strax norr om gravfältet norr om Lunnegården. En av vägarna går i västlig riktning genom Tunas bytomt (motsvarande dagens väg genom byn), den andra passerar gravfältet på östra sidan, fortsätter ner förbi Lunnegården och följer sjön ca 150-200 meter från stranden. Även mellan denna väg och runstenen är det 100 meter. Detta förefaller vara den äldsta vägen genom byns marker.

Med jämna mellanrum finns en Storåker eller ett Bredabol längs med denna väg. Detta är troligen "hemåkrar” till ett antal gårdar vars tomter bör ha funnits där åkrarna Husgården ligger. Husgården utgör ett oerhört starkt belägg för en tidigare bytomt. Tolkningen är något oklar, ägan kallas ibland Husgården, ibland Hedsgården, men bebyggelseindikerande är namnen hur som helst, där hus- är mest pregnant. Ytterligare namnindikationer på försvunna bebyggelse är Hallåker och Hallåkersfillen, Torget och Wigårdsfilen. 
En indikation att man är ett äldre gårdsläge på spåren är att leta efter bol, både som föroch efterled. Bolet var den mest högavkastande ängen och låg oftast helt nära gården. Bol-namn utslängda i ägorna indikerar således ett övergivet bebyggelseläge. Bol kan också betyda gårdstomt. I Tuna finns diverse bol, men de ligger mestadels intill de nuvarande gårdarna och hör således till dem, men just Bredabol och Bolet vid Storåkern kan vara indikationer på ett äldre bebyggelseläge.

Mycket talar således för att bebyggelsen i Tuna by omstrukturerats, oklart när. Ett äldre byläge kan anas i anslutning till den östra vägen genom bymarken, vilket innebär att byn ursprungligen legat både betydligt närmare sjön och närmare runstenen. Ska detta kopplas till traditionerna om att det tidigare ska ha legat en köping eller stad på Tunas ägor, vilket Bruzelius berättar om?

Däremot finns i kartmaterialet inga indikationer på ett gårdsläge invid runstenen. Det ska även noteras att runstenen står på Lunnegårdens marker, men en bra bit söder om det äldsta i kartorna identifierbara gårdsläget. Att Lunnegårdens åker och äng inte fullt ingår i byns tegskifte antyder att denna gård ursprungligen kan ha haft en särskild ställning i byn. Det är också möjligt att runstenen ska kopplas till denna gård, men samtidigt antyder kartan att det skett en total omorganisation av bebyggelselägena i Tuna. När detta skett är oklart, men det måste ha skett före 1703.

En annan intressant karta i sammanhanget är en storskifteskarta från 1778 över den samfällt ägda skogen, en s.k. skogelagskarta, till enheterna Tuna, Väraboda, Stora och Lilla Boaryd, Tranhult, Ottersnäs och Skeda (07-rys-112). Clas Tollin har för Smålands del diskuterat den samfällt ägda skogen och skogelagen och menar att de enheter som ingått i ett skogelag kan ha haft ett gemensamt ursprung. En av enheterna i skogelaget antas ha varit den ursprungliga bebyggelseenheten och de andra enheterna i skogelaget avgärda enheter till denna. Ursprungsenheten bör ha varit större och äldre än de andra. Skogelaget skulle således vara en rest av ett äldre ägoområde med rötter i tidig medeltid, där ursprungsenheten ofta har vikingatida gravfält, något som omgivande enheter saknar, Ofta nämns även ursprungsenheten först av de uppräknade enheterna i skogelaget (Tollin 1999, s. 65f, 70).

I det aktuella fallet förefaller Tollins antaganden korrekta. Tuna by är den enhet som nämns först av de uppräknade enheterna på kartan, det är den klart största enheten och den enhet som har flera vikingatida gravfält, medan övriga ingående enheter saknar gravfält av yngre järnålderskaraktär. Undantaget är en osäker hög i Boaryd som möjligen kan vara en rest av ett bortodlat gravfält.

I 1538-44 års jordeböcker bestod Tuna av sju gårdar, medan Väraboda, Boaryd, Ottersnäs och Skeda var ensamgårdar. I Tranhult fanns två gårdar, en av dessa låg dock öde (L-O Larsson 1978, s. 65f). Även när man tittar på ortnamnen kan man se att övriga ingående enheter har namn av yngre karaktär, medan Tuna och kanske möjligen även Skeda kan vara namn av förhistorisk karaktär. Den bild som framträder av skogelagskartan är således att Tuna ursprungligen kontrollerat ett stort område, på vars marker ett 


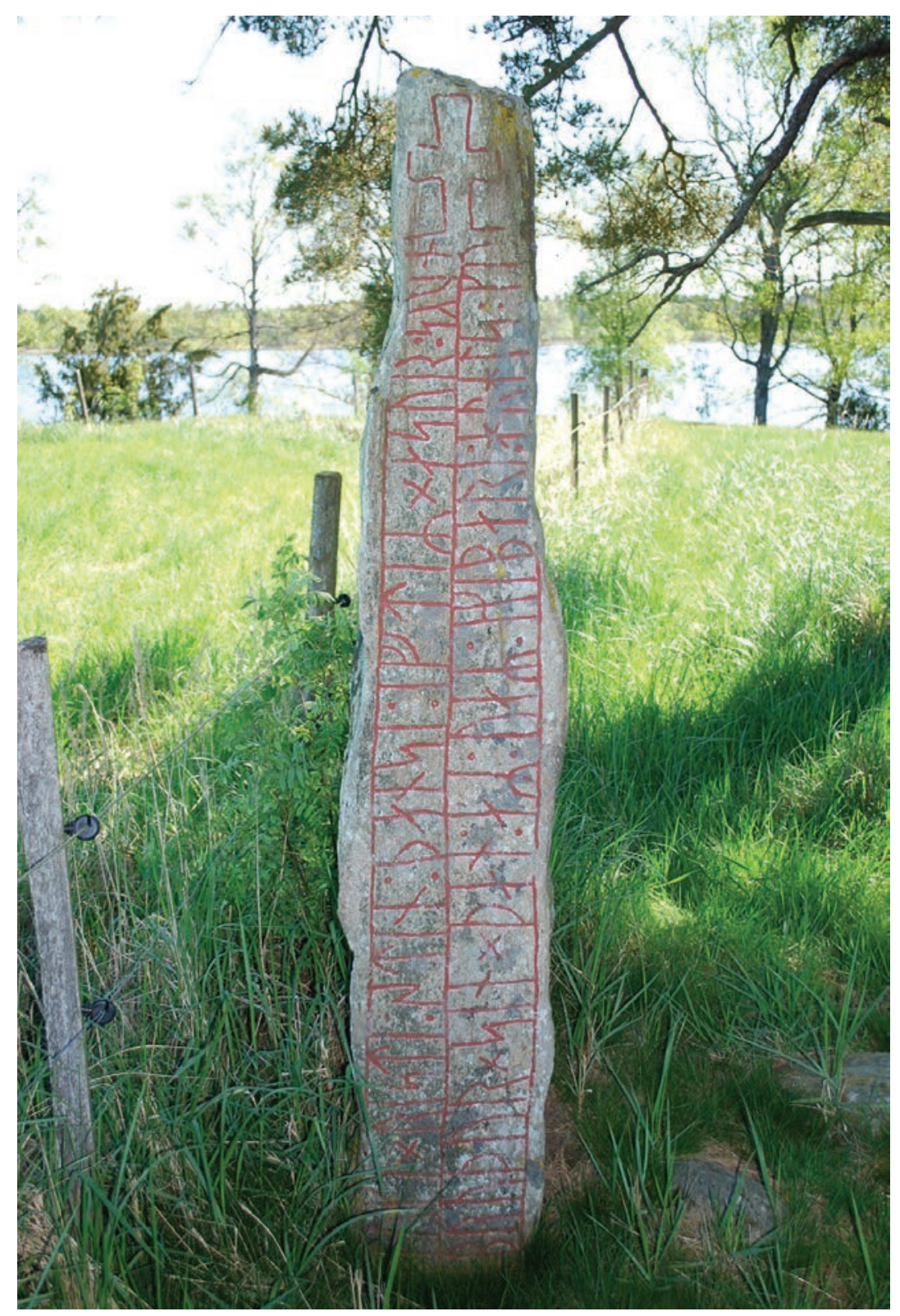

Fig 3. Runstenen Sm 42. I bakgrunden skymtar Ryssbysjön.

flertal enheter etablerats. Hypotetiskt sker denna kolonisation under tidig medeltid. Rent geografiskt ligger Tuna i det nordöstra hörnet av skogelaget, på den sandiga och lättodlade jorden invid Ryssbysjön, medan de sekundära enheterna etablerats i områdena söder och väster om Tuna.

\section{Runstenen}

Runstenen är första gången omnämnd i ett Rannsakningsprotokoll från 1667, ”Runesteen finns i Tuna gierde”. Även Liljegren (1833, s. 139) anger platsen som Tuna gärde, vid sjön. Runstenen är väl beskriven hos Kinander (1935, s. 130ff) och Helmer Gustavsson har nyligen bekräftat läsningen (Gustavsson 2008, s. 202). I de äldre beskrivningar som finns av runstenen finns inga indikationer på att den någonsin flyttats, vilket var anledningen till varför vi valde att undersöka just denna runsten.

Stenen, av rödaktig, medelkornig gnejs, är cirka två meter hög över markytan (fig. 3). Bredsidorna är ganska ojämna, knappt en meter breda, medan smalsidorna är mellan 20 


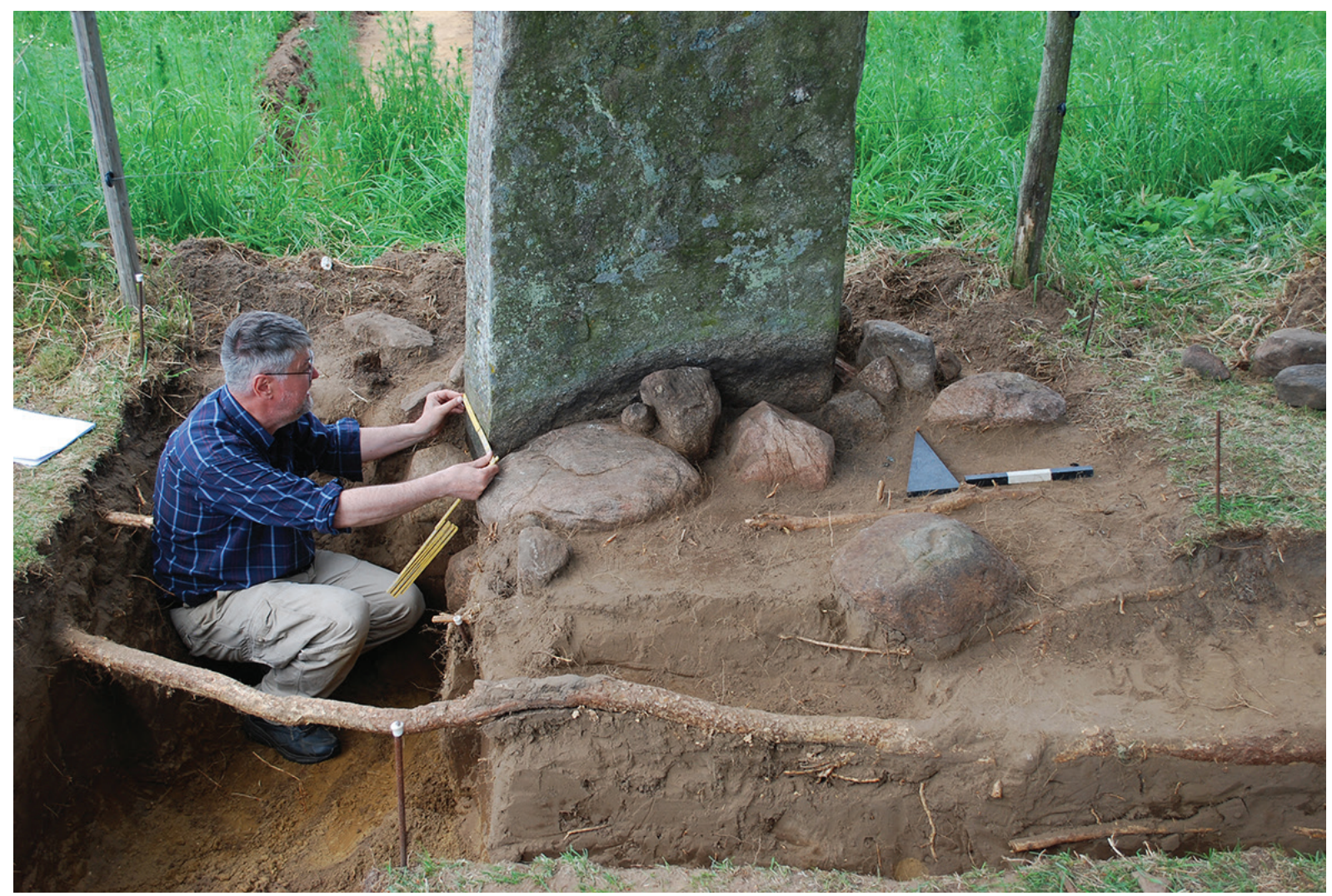

Fig.4. Per Stille dokumenterar runstenens textsida. Runt stenen syns den omgivande stenpackningen. Foto från söder, Martin Hansson.

till 40 centimeter breda. Trots det är det bara på den ena smalsidan som texten återfinns. Att på det här sättet ha texten enbart på ena smalsidan är något som gör stenen förhållandevis ovanlig. Texten finns på den smalsida som vänder sig åt väster. Denna sida är i princip helt är täckt av texten. Runinskriften består av två rader med runor som är cirka 11-15 centimeter stora. I slingans övre del är runorna något mindre, mellan 7-10 centimeter stora, kanske på grund av att ristaren fick ont om utrymme. Över runraderna finns ett inristat kors som är cirka 20x12 centimeter stort.

Runt runstenen finns en stenpackning. Denna framträdde redan innan grästorven lyftes bort och ursprungligen har den antagligen varit väl synlig runt runstenen. Den bör ses som en del av själva monumentet. Stenpackningen bestod av två distinkta lager av sten. Överst fanns en del löst liggande sten som förefaller ha hamnat runt runstenen i relativ sen tid, kanske i samband med röjnings-/odlingsaktiviteter på platsen, därunder framkom ytterligare sten som låg $\mathrm{i}$ en krans runt runstenen. Att döma av stenpackningens ytliga utbredning stod runstenen i en cirka 1,20 x 0,8 meter stor grop som fyllts med sand och större stenar som packats runt runstenen när denna restes.

Genom att gräva på runstenens västra sida (textsidan) bekräftades denna tolkning (fig 4). Det gick att fastställa att nederkanten av runstenen står cirka 0,75 meter under markytan (räknat från nedersta begränsningslinjen på runinskriften). Sammanlagt är alltså runstenen ca 2,75 meter hög räknat från topp till botten. Nedgrävningskanten till gropen var bortsett från stenfyllningen svår att iaktta varför nedgrävningen sannolikt 
dels är av hög ålder, dels är igenfylld med samma sand som först grävdes upp. Stenfyllningen i nedgrävningen var dock mycket tydlig eftersom de kringliggande lagren var helt stenfria. Att nedgrävningskanten till gropen var svår att se samt det förhållande att vi inte hittade några "moderna" föremål i gropfyllningen, gör att allt talar för att runstenen faktiskt står på den plats där den en gång restes. När Tumme för tusen år sedan bestämde sig för att resa runstenen så var det meningen att den skulle stå som den står idag, med texten på smalsidan synlig från väster och med sjön i bakgrunden.

Runinskriftens läsning är tämligen säker, däremot är det oklart vad termen skeppare/ skeppsman kan innebära och vem kung Harald var. För att avgöra det måste man försöka datera runstenen. Idag menar man att den här typen av oornerade stenar ska dateras till tidigt tiohundratal c. 980-1015 (Gräslund 2002, s. 147; 2006, s. 126). Likartade runstenar som talar om Englandsfärder, brukar sättas i samband med tiden för vikingarnas våg av stora angrepp på England som startar 990 och avslutas med den danske kungen Knut den stores stora gäld 1018. Den Harald som omtalas på stenen är därför troligen den danske kungen Harald Svensson som regerade åren 1014-1018, då han efter sin död efterträddes av brodern Knut (den Store). Man kan kanske inte helt utesluta att den Harald det handlar om skulle vara Harald Gormsson, också känd som Harald Blåtand och farfar till Harald Svensson. Harald Gormsson reste den magnifika runstenen i Jelling på Jylland, där han förklarar att det var han som enade danerna och gjorde dem kristna. Men den kung Harald som omtalas kan ju också vara en person som antagit kunganamn utan att lämna spår i källorna. Är det Harald Svensson som avses kan runstenen tidigast vara rest 1014. Möjligen är det så att runstenen rests under dennes regeringstid eller relativt kort efter hans död (Gustavsson 2008, s. 202; Stille 2008, s. 74). När det gäller en titel som skeppsman/skeppare är dess exakta betydelse oklar. En del forskare har menat att det avser en person som var befälhavare på ledungsskeppen, en verklig högstatusposition i det vikingatida samhället. Andra menar att den istället avser personer som var besättningsmän på ledungsskeppen (Randsborg 1980, s. 34; Sawyer, 2002, s. 70; Gustavsson 2008, s. 202).

En intressant detalj som framkom vid undersökningen kan ha samband med själva resandet av runstenen. Strax sydväst om runstenen framkom ett stolphål kantat med stenar cirka 0,4 meter under markytan. Det var grävt igenom det neolitiska kulturlager som fanns på platsen, men inte så djupt så att det gick ned i den sterila sanden. Sammantaget antyder detta att stolphålet inte tillhör den neolitiska bebyggelsen utan ett yngre skede. Möjligen har här stått en stolpe som använts i samband med själva resandet av runstenen. Hur det praktiska resandet av runstenar gått till vet vi egentligen inget om. Möjligen har vi här en ledtråd till att det förekommit någon form av lyftanordning.

Gemensamt för den moderna forskningen kring runstenar är synen på runstenar som metaforer för andra förhållanden i samhället. Sedan 1980-talet har arkeologer använt runstenar för tolkningar av sociala sammanhang, där exempelvis analyser av olika titlar, som "thegn" och “dreng" varit i fokus (Randsborg 1980; Christophersen 1982). Användningen av runstenar i ett socialt sammanhang och som bakgrund till medeltida förhål- 
landen har varit vanligt inom forskningen (Riddersporre 1989; Anglert 1995; Hansson 2001). Bakom dessa tolkningar ligger synen att runstenarna restes av samhällets överklass, storbönder och lokala hövdingafamiljer. Det var dessa som hade råd att bekosta uppförandet av monumenten. Orsaken till runstensresandet var sannolikt flerfaldig, bl. a. omtalas många gånger arvsförhållanden, men gemensamt för alla runstenar är att de också fungerat som statusmarkörer och använts för att manifestera gamla eller nya sociala förhållanden. Mot denna bakgrund och de resultat som undersökningen gav kan man nu börja fundera över hur runstenens vikingatida mikrotopografi gestaltat sig i detalj $i$ Tuna. Även om mycket fortfarande är oklart går det att börja skissa på det sammanhang i vilket runstenen en gång restes och skapa ett antal hypoteser som kan vara utgångspunkt i det fortsatta arbetet.

\section{Runstenen, gravarna och vägen}

Man kan med största säkerhet anta att runstenen står orubbad på sin ursprungliga plats. Generellt menar Torun Zachrisson utifrån sin studie av runstenar i Uppland att runstenar antingen restes i samband med att något skapades, man gjorde bro, vad, tingsplats o dyl. och reste samtidigt runsten, eller så restes stenen på redan etablerade platser i landskapet (Zachrisson 1998, s. 168). Det senare var fallet med runstenen i Tuna. Den restes i anslutning till, men en bit ifrån, ett gravfält som fanns på platsen. Även om ingen av gravarna i anslutning till runstenen är undersökt, är gravfält med högar i regionen alltid daterade till yngre järnålder i de fall de är undersökta (Hansson 1998). Därför har förfädernas gravar funnits på platsen när man i början av tiohundratalet bestämde sig för att resa runstenen här. Men runstenen ställdes inte alldeles invid gravarna utan en bit bort. Kanske beror avståndet till gravarna på att stenen är kristen, medan förfäderna i gravarna sågs som hedningar. Däremot har runstenen inte rests i anslutning till en vikingatida bebyggelse. Undersökningen visade att det inte funnits någon sådan inom de närmsta 50-80 metrarna väster och norr om runstenen (i söder fanns gravfältet, i öster sjön). Det fanns inte heller spår efter några ritualer som genomförts vid runstenen. Det gick inte heller att belägga förekomst av någon väg i området omedelbart väster om runstenen. Rester efter en sådan kan dock ha odlats bort för länge sedan, och den sandiga markens beskaffenhet gör att någon direkt vägbeläggning inte var nödvändig.

Den närmsta väg som gick förbi runstenen fanns att döma av 1801 års karta cirka 100 meter längre västerut. På det avståndet går det inte att urskilja att det fanns runor på den resta stenen invid gravfältet. För en förbipasserande på den vägen framstod runstenen då snarast som en "vanlig” rest sten, en typ av gravform som användes under järnålder i regionen (Hansson 1998). Detta intryck måste ha förstärkts av att man samtidigt har sett de runda gravhögarna strax söder om runstenen. För att uppfatta att här stod en runsten måste man komma närmre. Detsamma gäller även om det funnits en vinterväg över Ryssbysjöns is (jfr Larsson 1999, s. 102). Även då har runstenen framstått som en "vanlig” rest sten, kanske ännu mer, eftersom texten inte varit synlig från sjösidan. Att texten vänder sig åt väster visar att den var tänkt att ses från detta håll. 
Det kan ju inte uteslutas att en vikingatida föregångare till vägen på 1801 års karta gick invid runstenen, inte minst med tanke på att byn verkar ha omstrukturerats mycket grundligt, vilket kan ha förändrat vägnätet. Samtidigt, den väg som i så fall närmast passerat runstenen har antagligen haft karaktären av lokalväg. Vägen har gått längs sjön till Skeda och vidare söderut. Att rekonstruera vikingatidens vägnät är dock inte helt enkelt (jfr. Brink 2002, s. 104). Utdikningar, sjösänkningar och andra ingrepp i landskapet gör att detta idag ser helt annorlunda ut jämfört med för tusen år sedan. Det enklaste sättet att få en överblick över ett äldre vägnät är att använda de häradskartor som utarbetades under 1600-talets mitt och andra hälft. Kartorna är inbördes lite olika, men markerar dåtidens viktigaste större vägar mellan kyrkor, byar och tingsplatser. Ofta har lantmätarna karterat vägarna på skilda sätt så att vissa vägar framstår som viktigare än andra. Eftersom en hel del av dessa äldre vägsträckningar fortfarande kan återfinnas i landskapet, och dessa vägar ofta kantas av fornlämningar från både brons- och järnålder, kan man utgå ifrån att många av de vägar som karterats på häradskartorna faktiskt kan gå tillbaka till vikingatid, om inte ännu äldre perioder.

På 1685 års häradskarta över Sunnerbo, där Tuna ligger, finns två sorters vägar markerade, dels dubbelsträckade vägar som förefaller ha varit huvudvägar, dels enkelsträckade vägar som mer har karaktär av lokalväg mellan enskilda byar. Dessutom måste det ha det funnits vägar av ännu lägre dignitet som inte är markerade på kartan, eftersom det saknas vägar fram till en hel del bebyggelseenheter. Vägen genom Tuna är enkelsträckad på kartan (och går inte intill sjön utan i sitt sentida läge enligt 1801 års karta, en bit väster om sjön), medan en dubbelstreckad huvudväg passerade Ryssby och fortsatte västerut mot Tutaryd. De här två vägarna delade sig vid en bro över det vattendrag som rinner ut i Ryssbysjön norr om Lunnegård (fig. 5). Själva vägskälet låg väster om Lunnegård och en bit norr om bytomten i Tuna. Någon huvudväg av "högsta klass" har således antagligen inte passerat runstenen. Hade man velat att "alla” förbipasserande skulle se den, skulle man ställt runstenen i ett mer offentligt läge vid bron istället. Nu framstår runstenen närmast som en intern angelägenhet för byn. Kanske kan man säga att den vänder sig inåt mot det egna lokalsamhället, snarare än att den kommunicerar utåt.

\section{Runstenen och bebyggelsen}

Runstenens förhållande till gårdarna i byn är problematisk att diskutera eftersom kartan från 1801 antyder att bebyggelsen omstrukturerats. Vi vet att kartans bebyggelselägen inte avspeglar en äldre situation. Men mycket tyder ändå på att runstenen ska kopplas till Lunnegård i norr. Att större delen av denna gårds ägor inte ingår i byns gemensamma tegskifte antyder att den alltid legat för sig själv, närmast i en form av hemägoblock, vilket skulle kunna indikera att gården har fungerat separerad för den övriga byn. Detta skulle hypotetiskt kunna indikera en ursprunglig storgård i byn (jfr, Widgren 1997, s. 54; Hansson 2001, s. 154ff; Tollin 2010, s. 132). Runstenen, vars existens i byn talar för att det verkligen funnits en storgård, verkar ha stått i södra delen av denna gårds 
ägor. Kanske har den till och med markerat gränsen för gårdens ägor mot övriga byn (jfr Zachrisson 1998, s. 194). Sammantaget antyder det att runstenen ska ses som en intern maktdemonstration, där Tumme och hans familj genom stenen markerade sin överhöghet i lokalsamhället. Är stenen rest för att avgöra en intern maktkamp i byn, eller för att markera att byns ledande familj nu kristnats (korset) och har kontakter med kung Harald? Att samtiden visste vilken Harald som avsågs kan vi nog utgå ifrån.

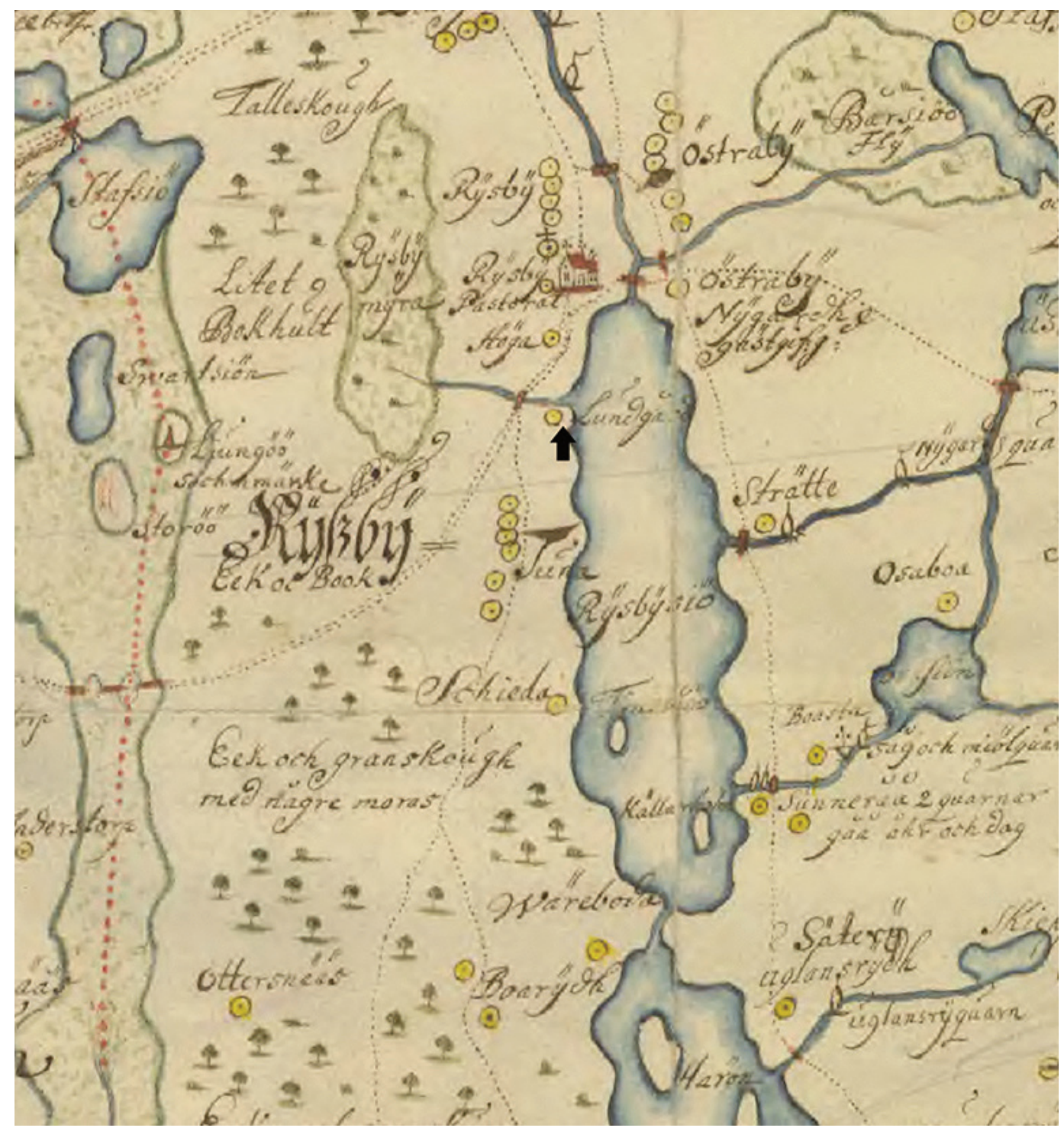

Fig 5. Utdrag ur häradskartan över Sunnerbo från 1685. Runstenens ungefärliga läge är markerat med en svart pil. Av kartan framgår hur huvudvägen från Ryssby viker av västerut efter passagen av den lilla ån strax nordväst om Lunnegård, medan lokalvägen söderut fortsätter genom Tunas bytomt. Lunnegård och runstenens avskilda läge vid strandkanten framgår tydligt.

Men man kan även fundera ytterligare kring runstenens plats i landskapet. Som Anders Andrén har visat fanns det en tanke bakom utformningen av runslingan och dess tillhörande ornament, kompositionen av text och bild har haft betydelse och kan tolkas kontextuellt (Andrén 2000). På runstenen i Tuna finns bortsett från det kristna korset 
inga bilder så här kan just den diskussionen inte föras. Däremot kan man fundera på om det fanns någon särskild tanke bakom stenens placering, textens innehåll och annat som är synligt medan man läser texten. Fanns det en medveten tanke bakom det faktum att man under läsningen av texten, som berättar om Assur, kung Haralds skeppare, samtidigt ser sjön och vattnet i bakgrunden? Har detta använts för att ytterligare understryka textens innehåll och vikten av Assurs tjänst hos kung Harald?

\section{Slutord}

Genom att på det här sättet i detalj undersöka hur runstenar placerats i landskapet ges en möjlighet att diskutera vad som låg bakom att de just står på de platser där det står. En del av det som presenterats ovan om runstenen i Tuna är hypoteser, men genom att studera alla de 39 runstenar i Tiohärad vars ursprungliga placering är känd finns möjlighet att testa en del av dessa. Inte minst är det intressant att se hur runstenarna förhåller sig till vägar av olika dignitet. En del stenar förefaller ha stått i offentliga lägen, medan andra restes mer avskilt. När det gäller stenen i Tuna har kunskapen ökat och vi har kunnat formulera en del hypoteser och tolkningar. Bröderna Assur och Tumme bodde antagligen på storgården i den norra delen Tuna. Även om det inte uttryckligen står att Assur är död är runstenen ändå ett minnesmonument över honom, varför vi kan anta att Tumme reste stenen för att markera att det nu var han som tagit arv av Assur. Genom att resa stenen invid gravarna, på gränsen mot de andra gårdarna gjorde Tumme en tydlig markering av sin position i byn, bland annat genom att anknyta till förfäderna. Omnämnandet av kung Harald bidrog ytterligare till att visa vilka kontakter familjen hade. Läget på byns ägor nere vid sjön långt från allfartsvägen tyder samtidigt på att det var ett internt budskap som skulle förmedlas, annars skulle sannolikt läget vid bron vid den större vägen valts. Men samtidigt återstår en mängd frågor, inte minst - hur kunde en landkrabba från Tuna by i Smålands inland bli skeppsman hos kung Harald?

Tack till Ingrid Gustin för värdefulla synpunkter på texten, samt till Ådel VestböFranzen för hennes arbete med de historiska kartorna.

\section{Referenser}

Andreeff, Alexander, (2012), Arkeologiska utgrävningar av bildstensplatser. Gotländskt arkiv. s. $129-144$.

Andrén, Anders, (2000), Re-reading Embodied Texts - an Interpretation of Rune-stones. Current Swedish Archaeology vol. 8. s. 7-32.

Anglert, Mats, (1995), Kyrkor och herravälde. Från kristnande till sockenbildning i Skåne. Lund Studies in Medieval Archaeology 16. Lund.

Brink, Stefan, (2002). Runstenar och gamla vägar i norra Småland. Om runstenar i Jönköpings län. (red. Agertz, J. och Varenius, L.) Småländska kulturbilder 2002. Jönköping: Jönköpings läns museum. s. 101-118. 
Christophersen, Axel, (1982), Drengs, Thegns, Landmen and Kings. Some Aspects on the Forms of Social Relations in Viking Society during the Transition to Historic Times. Meddelanden från Lunds universitets historiska museum 1981-82. s. 115-134.

Gräslund, Ann-Sofie, (2002), De senvikingatida runstenarna i Jönköpings län - deras ornamentik och datering. Om runstenar i Jönköpings län. (red. Agertz, J. och Varenius, L.) Småländska kulturbilder 2002. Jönköping: Jönköpings läns museum. s. 139-154.

Gräslund, Ann-Sofie, (2006), Dating the Swedish Viking-Age rune stones on stylistic grounds. Runes and their Secrets. Studies in runology. Copenhagen. s. 117-140. Gustavsson, Helmer, (2008), Katalog över runinskrifter i Kronobergs län. Runor i Kronobergs län. Kronobergsboken. Red M Hansson \& P Stille. s. 113-227.

Hansson, Martin, (1998), Graves, Grave-Fields and Burial Customs - Variation as Theme. A discussion of Late Iron Age Grave-Fields in the Inland of Småland. Lund Archaeological Review 4, s. 49-66.

Hansson, Martin, (2001), Huvudgårdar och herravälden. En studie av småländsk medeltid. Lund studies in medieval archeology 25. Almqvist \& Wiksell International: Stockholm.

Hansson, Martin, \& Stille, Per, (2014), Runstenen i Tuna, Sm 42. Arkeologisk forskningsundersökning 2013. Rapporter från Institutionen för arkeologi och antikens historia. Nr 11.

Holmberg, Karl Axel, (1969), De svenska Tuna-namnen. Uppsala.

Hyenstrand, Åke, (1982), Om Tuna-problemet och den territoriella indelningen. Bebyggelsehistorisk tidskrift $1982 \mathrm{nr}$ 4. s. 83-88.

Jansson, Sven B F, (1978), Ryssby sockens runstenar. En bok om Ryssby i Sunnerbo Kronobergs län utgiven av Bertil Bexell. Växjö. s. 99-106.

Kinander, Ragnar, (1935) Smålands runinskrifter. Sveriges runinskrifter. Fjärde bandet, första häftet. Kronobergs län. Kungl. Vitterhets Historie och Antikvitets Akademien. Stockholm.

Knutsson, Christer, (1995), Tunamynten - ett okänt myntfynd från vikingatid. Sunnebokrönika del I. Från äldsta tider till omkring 1600. Red M Eriksson, P-O Marke, O Rendell. Ljungby. s. 45.

Larsson, Gunvor, (1978), Vikingatida depåfynd i Småland. C-uppsats i arkeologi vid Lunds universitet. Stencil.

Larsson, Lars-Olof, (1978), Tusen år i Ryssby. En finnvedssocken från vikingatid till 1800tal. I En bok om Ryssby i Sunnerbo, Kronobergs län. Red B Bexell. Växjö. s. 7-98.

Larsson, Lars-Olof, (1999), Land och län under kristendomens millenium. I Landen kring sjöarna. En historia om Kronobergs län i mångtusenårigt perspektiv. Red. L. Johansson. Kronobergsboken 1999-2000. s. 61-274.

Liljegren, Johan Gustaf. (1833), Run-urkunder. Stockholm.

Ljung, Cecilia, \& Thedéen, Susanne, (2009), Ritualer vid runstenar? En arkeologisk undersökning invid Ängbystenen i Bromma. Institutionen för arkeologi och antikens kultur. Stockholms universitet. Rapport.

Olsson, Ingmar, (1976), Tuna-namnen i Sverige - forskningsläget. Fornvännen 71. s. 72-81. Randsborg, Klaus, (1980), The Viking Age in Denmark. The Formation of a State. London. 
Rannsakningar efter antikviteter. Band 3, Öland Småland, Blekinge, Halland, Skåne, utgivet av N-G Stahre. 1992. Stockholm.

Riddersporre, Mats, (1989), Lantmäterihandlingar, runstenar och huvudgårdar. Några kommentarer och spekulationer i ett lokalt geografiskt perspektiv. By, huvudgård och kyrka. Studier i Ystadsområdets medeltid red Andersson H \& Anglert M. Lund Studies in Medieval Archaeology 5. Stockholm. s. 134-144.

Sawyer, B. (2002). Runstenar och förmedeltida arvsförhållanden. Om runstenar i Jönköpings län. (red. Agertz, J. och Varenius, L.) Småländska kulturbilder 2002. Jönköping: Jönköpings läns museum. s. 55-78.

Stille, Per, (2007), Runstenarnas plats i det mentala och sociala landskapet i tiohundratalets Tiohärad. En skiss till ett forskningsprojekt. Urminne - tidskrift för arkeologi för sydöstra Sverige. 2007/6. s. 51-55

Stille, Per, (2008), ’Runstenar och runresare i Småland.” Runor i Kronobergs län. Kronobergsboken. Red M Hansson \& P Stille. s. 72-84

Tollin, Clas, (1991), Ättebackar och ödegärden. De äldre lantmäterikartorna i kulturmiljövården. Riksantikvarieämbetet.

Tollin, Clas, (1999), Rågångar, gränshallar och ägoområden. Rekonstruktion av fastighetsstruktur och bebyggelseutveckling i mellersta Småland under äldre medeltid. Meddelande nr 101. Kulturgeografiska institutionen, Stockholms universitet.

Tollin, Clas, (2010), Ägodomäner och sockenbildning i västra Östergötland. En rumslig studie om kyrkliga upptagningsområden och ägarförhållanden vid tiden för Alvastra klosters grundande. SLU Rapport 167. Uppsala.

Widgren, Mats, (1997), Bysamfällighet och tegskifte i Bohuslän 1300-1750. Skrifter utgivna av Bohusläns museum och Bohusläns hembygdsförbund nr 60.

Zachrisson, Torun, (1998), Gård, gräns, gravfält. Sammanhang kring ädelmetalldepåer och runstenar från vikingatid och tidigmedeltid i Uppland och Gästrikland. Stockholm Studies in Archaeology 15.

\section{Kartmaterial}

F59-55:3 Tuna 1-7, Storskifte på inägor, 1801. Karl Johan Lagerbjelke.

F59-55:1 Tuna 1-7. Geometrisk avmätning 1703. Peter Hamnel.

F59-55:2 Tuna 1-7. Storskifte, Tuna skogelag 1778. Lars Elmqvist.

07-rys-112 Storskifte, Tuna skogelag 1778. Lars Elmqvist. 